
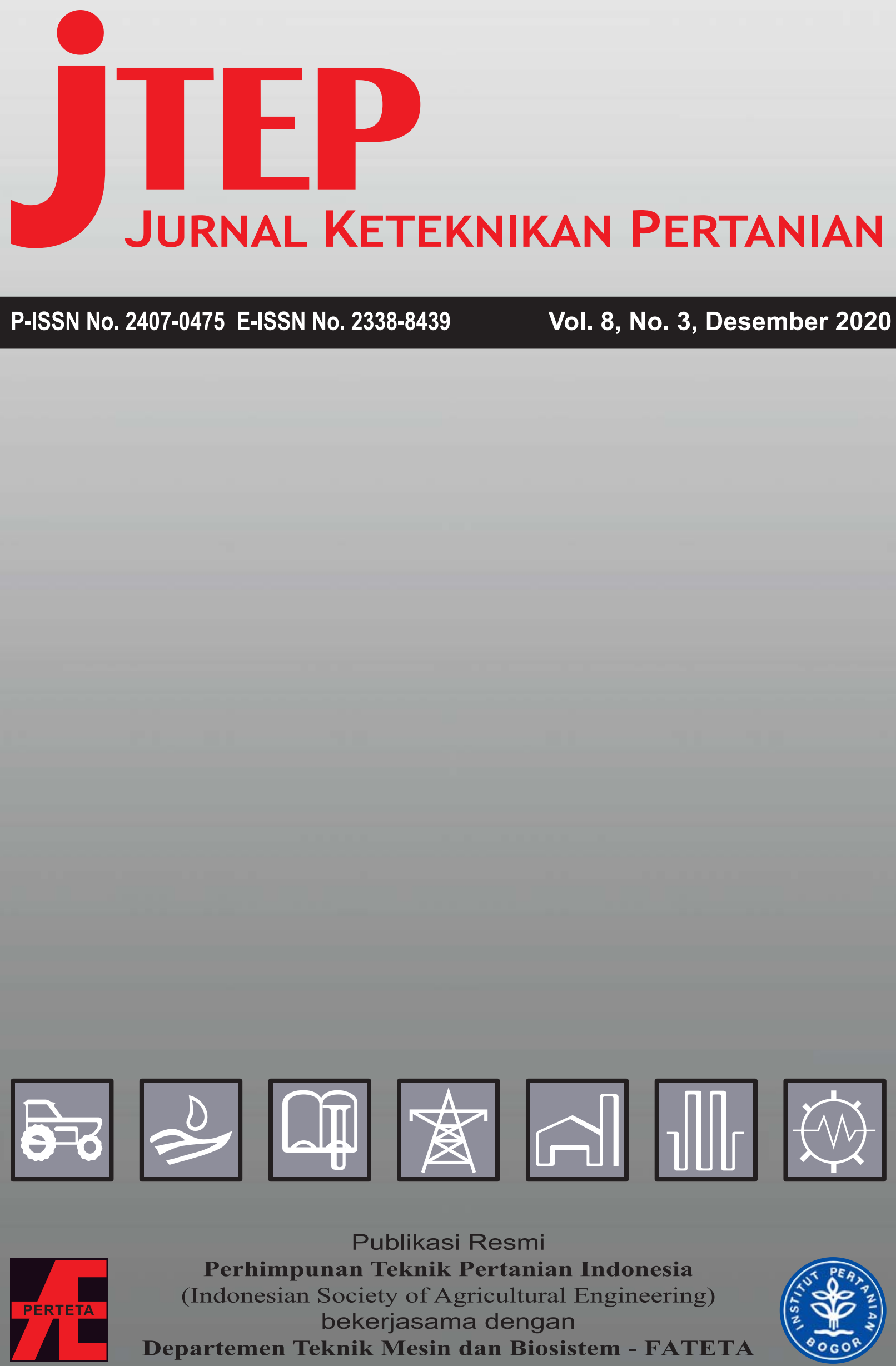

\footnotetext{
Publikasi Resmi

Perhimpunan Teknik Pertanian Indonesia (Indonesian Society of Agricultural Engineering) bekerjasama dengan Departemen Teknik Mesin dan Biosistem - FATETA Institut Pertanian Bogor
}

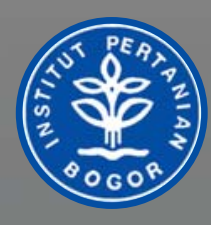




\section{jTEP JURnal Keteknikan Pertanian}

Vol. 8, No. 3, Desember 2020

Jurnal Keteknikan Pertanian (JTEP) terakreditasi berdasarkan SK Dirjen Penguatan Riset dan Pengembangan Kementerian Ristek Dikti Nomor I/E/KPT/2015 tanggal 21 September 2015. Selain itu, JTEP juga telah terdaftar pada Crossref dan telah memiliki Digital Object Identifier (DOI) dan telah terindeks pada ISJD, IPI, Google Scholar dan DOAJ. JTEP terbit tiga kali setahun yaitu bulan April, Agustus dan Desember, Jurnal berkala ilmiah ini berkiprah dalam pengembangan ilmu keteknikan untuk pertanian tropika dan lingkungan hayati. Penulis makalah tidak dibatasi pada anggota PERTETA tetapi terbuka bagi masyarakat umum. Lingkup makalah, antara lain meliputi teknik sumberdaya lahan dan air, alat dan mesin budidaya pertanian, lingkungan dan bangunan pertanian, energi alternatif dan elektrifikasi, ergonomika dan elektronika pertanian, teknik pengolahan pangan dan hasil pertanian, manajemen dan sistem informasi pertanian. Makalah dikelompokkan dalam invited paper yang menyajikan isu aktual nasional dan internasional, review perkembangan penelitian, atau penerapan ilmu dan teknologi, technical paper hasil penelitian, penerapan, atau diseminasi, serta research methodology berkaitan pengembangan modul, metode, prosedur, program aplikasi, dan lain sebagainya. Penulisan naskah harus mengikuti panduan penulisan seperti tercantum pada website dan naskah dikirim secara elektronik (online submission) melalui http://journal.jpb.ac.id/index.php/jtep.

\section{Penanggungjawab:}

Ketua Departemen Teknik Mesin dan Biosistem, Fakultas Teknologi Pertanian,IPB

Ketua Perhimpunan Teknik Pertanian Indonesia

\section{Dewan Redaksi:}

Ketua : Yohanes Aris Purwanto (Scopus ID: 6506369700, IPB University)

Anggota : Abdul Hamid Adom (Scopus ID: 6506600412, University Malaysia Perlis)

(editorial Addy Wahyudie (Scopus ID: 35306119500, United Arab Emirates University)

board) Budi Indra Setiawan (Scopus ID: 55574122266, IPB University)

Balasuriya M.S. Jinendra (Scopus ID: 30467710700 , University of Ruhuna)

Bambang Purwantana (Scopus ID: 6506901423, Universitas Gadjah Mada)

Bambang Susilo (Scopus ID: 54418036400, Universitas Brawijaya)

Daniel Saputera (Scopus ID: 6507392012, Universitas Sriwjaya)

Han Shuqing (Scopus ID: 55039915600, China Agricultural University)

Hiroshi Shimizu (Scopus ID: 7404366016, Kyoto University)

I Made Anom Sutrisna Wijaya (Scopus ID: 56530783200, Universitas Udayana)

Agus Arif Munawar (Scopus ID: 56515099300, Universitas Syahkuala)

Armansyah H. Tambunan (Scopus ID: 57196349366, IPB University)

Kudang Boro Seminar (Scopus ID: 54897890200, IPB University)

M. Rahman (Scopus ID: 7404134933, Bangladesh Agricultural University)

Machmud Achmad (Scopus ID: 57191342583, Universitas Hasanuddin)

Muhammad Makky (Scopus ID: 55630259900, Universitas Andalas)

Muhammad Yulianto (Scopus ID: 54407688300, IPB University \& Waseda University)

Nanik Purwanti (Scopus ID: 23101232200, IPB University \& Teagasc Food Research Center Irlandia)

Pastor P. Garcia (Scopus ID: 57188872339 , Visayas State University)

Rosnah Shamsudin (Scopus ID: 6507783529, Universitas Putra Malaysia)

Salengke (Scopus ID: 6507093353, Universitas Hasanuddin)

Sate Sampattagul (Scopus ID: 7801640861, Chiang Mai University)

Subramaniam Sathivel (Scopus ID: 6602242315, Louisiana State University)

Shinichiro Kuroki (Scopus ID: 57052393500, Kobe University)

Siswoyo Soekarno (Scopus ID: 57200222075, Universitas Jember)

Tetsuya Araki (Scopus ID: 55628028600, The University of Tokyo)

Tusan Park (Scopus ID: 57202780408, Kyungpook National University) 


\section{Redaksi Pelaksana:}

Ketua : : Usman Ahmad (Scopus ID: 55947981500, IPB University)

Sekretaris : Lenny Saulia (Scopus ID: 16744818700, IPB University)

Bendahara : Dyah Wulandani (Scopus ID: 1883926600, IPB University)

Anggota : Satyanto Krido Saptomo (Scopus ID: 6507219391, IPB University)

Slamet Widodo (Scopus ID: 22636442900, IPB University)

Liyantono (Scopus ID: 54906200300, IPB University)

Leopold Oscar Nelwan (Scopus ID: 56088768900, IPB University)

I Wayan Astika (Scopus ID: 43461110500, IPB University)

Agus Ghautsun Niam (Scopus ID: 57205687481, IPB University)

Administrasi : Khania Tria Tifani (IPB University)

Penerbit: Departemen Teknik Mesin dan Biosistem, Institut Pertanian Bogor bekerjasama dengan Perhimpunan Teknik Pertanian Indonesia (PERTETA).

Alamat: Jurnal Keteknikan Pertanian, Departemen Teknik Mesin dan Biosistem, Fakultas Teknologi Pertanian, Kampus Institut Pertanian Bogor, Bogor 16680.

Telp. 0251-8624 503, Fax 0251-8623 026,

E-mail: jtep@apps.ipb.ac.id

Website: http://journal.ipb.ac.id/index.php/jtep

Rekening: BRI, KCP-IPB, No.0595-01-003461-50-9 a/n: Jurnal Keteknikan Pertanian

Percetakan: PT. Binakerta Makmur Saputra, Jakarta 


\section{Ucapan Terima Kasih}

Redaksi Jurnal Keteknikan Pertanian mengucapkan terima kasih kepada para Mitra Bebestari yang telah menelaah naskah pada penerbitan Vol. 8, No. 3 Desember 2020. Ucapan terima kasih disampaikan kepada: Prof.Dr.Ir. Lilik Soetiarso (Universitas Gadjah Mada), Dr.Ir. Lady Lengkey, M.Si (Universitas Sam Ratulangi), Ir. Siti Mariana Widayanti, M.Si, (Balai Besar Penelitian dan Pengembangan Pascapanen Pertanian), Dr.Ir. Lilik Pujantoro Eko Nugroho, M.Agr (Departemen Teknik Mesin dan Biosistem, IPB University), Dr.Ir. Emmy Darmawati, M. Si (Departemen Teknik Mesin dan Biosistem, IPB University), Dr. Andasuryani, S.TP, M.Si (Universitas Andalas), Ahmad Thoriq, S.TP, M.Si (Universitas Padjadjaran) 
jiep Jurnal Keteknikan Pertanian 
Technical Paper

\title{
Rancang Bangun dan Pengujian Penghalang Heliks sebagai Pencampur Udara-Biogas pada Motor Otto
}

\author{
Design and Testing of Helical Barriers as an Air-Biogas Mixer on the Otto Motor \\ Herbert Hasudungan Siahaan, Universitas Mpu Tantular. \\ Email: herbert9an@gmail.com \\ Armansyah Halomoan Tambunan, Departemen Teknik Mesin dan Biosistem, IPB University. \\ Email: ahtambun@yahoo.com \\ Desrial, Departemen Teknik Mesin dan Biosistem, IPB University. \\ Email: desrial_ipb@yahoo.com \\ Soni Solistia Wirawan, Badan Pengkajian dan Penerapan Teknologi (BPPT). \\ Email: sswirawan@yahoo.com
}

\begin{abstract}
A helical barrier as air-biogas mixing device was designed and tested for direct use of biogas from digester in otto cycle generator set. Homogeneity of the air-fuel mixture can give better combustion reaction and increase engine power. The design was based on simulation, which shows that a $0.039 \mathrm{~m}$ length of helical barrier gave a $5 \%$ increase in power compared to non-helical barrier. Likewise, the simulations also showed that the helical barrier reduced specific fuel consumption (SFC) by $8 \%$. Accordingly, the mixer with helical barrier was designed, and fabricated. Its performance test confirms the improvement resulted by using helical barriers as air-biogas mixer in the engine. The experiment showed that the power increased by $5 \%$ when using helical barrier, while SFC decreased by $4.5 \%$. It is concluded that the helical barrier can increase the homogeneity of the mixture resulting in better engine performance. Besides, emissions produced from the engine using a helical barrier also had an impact on reducing CO emissions by $10 \%$ and $H C$ by 1.5 times as a result of using biogas with stoichiometric AFR to produce relatively more complete combustion.
\end{abstract}

Keywords:helical barrier, biogas, engine performance, environmentally friendly emissions.

\begin{abstract}
Abstrak
Penghalang heliks sebagai pencampur udara-bahan bakar biogas telah dirancang bangun dan diuji untuk penggunaan biogas secara langsung dari digester pada motor Otto 4-langkah silinder tunggal penggerak generator listrik. Homogenitas campuran udara dan bahan bakar dapat menghasilkan pembakaran yang lebih baik dalam memaksimalkan tenaga mesin. Hasil simulasi menunjukkan bahwa penghalang heliks sepanjang $39 \mathrm{~mm}$ sebagai sistem pencampur udara-biogas dapat meningkatkan daya luaran sebesar $5 \%$ dan menurunkan konsumsi bahan bakar spesifik sebesar $8 \%$. Hasil uji performansi terhadap rancang bangun yang didasarkan pada simulasi tersebut juga menunjukkan hal yang sesuai, yaitu peningkatan $5 \%$ daya dan penurunan $4,5 \%$ konsumsi bahan bakar spesifik. Disamping itu, penggantian karburator dengan sistem pencampur hasil rancangan juga berdampak pada penurunan emisi CO sebesar $10 \%$ dan $\mathrm{HC}$ sebesar 1.5 kali sebagai akibat penggunaan biogas dengan AFR stoikiometrik untuk menghasilkan pembakaran relatif lebih sempurna.
\end{abstract}

Kata kunci: penghalang heliks, biogas, kinerja mesin, emisi ramah lingkungan.

Diterima: 3 Februari 2020; Disetujui: 22 September 2020 


\section{Pendahuluan}

Biogas sebagai bahan bakar yang mengandung energi metan sangat logis untuk dikembangkan secara berkesinambungan. Biogas mengandung gas metan dapat digunakan sebagai bahan bakar untuk menghasilkan energi pembakaran. Komposisi biogas dari limbah ternak didominasi oleh gas metan, $\mathrm{CO}_{2}$ dan sedikit unsur ikutan lain. Secara umum kandungan biogas dengan komponen utama gas metan pada kisaran sekitar $45-70 \%$ dari reaktor digester merupakan hidrokarbon yang paling sederhana dengan wujud gas dan telah digunakan sebagai bahan bakar (Dieter dan Steinhauser (2008). Proses pembakaran biogas relatif sama seperti bahan bakar bensin pada motor Otto, yaitu udara dan biogas secara bersama-sama masuk ke ruang bakar dan pada akhir langkah kompresi terjadi pembakaran oleh loncatan api busi. Motor Otto hingga kapasitas 100 kW dapat dihasilkan dengan menggunakan bahan bakar biogas dengan kandungan minimum 45\% metana (Theodorita et al. 2008). Sejumlah penelitian biogas sebagai bahan bakar telah dilakukan dengan sistim pemasukan bahan bakar ke dalam ruang bakar melalui intake manifold (Rosli 2002; Kumar et al. 2014; Awogbemi et al. 2015).

Perbedaan properti biogas dengan bahan bakar bensin memerlukan perlunya modifikasi sistim pemasukan campuran udara-bahan bakar pada saluran utama udara sebelum intake manifold untuk menyesuaikan pada kondisi pembakaran mesin berbahan bakar bensin (Mitzlaff 1988; Rosli 2002). Memodifikasi sistim pemasukan biogas dianggap lebih mudah dan murah dibandingkan dengan perlakuan lain pada ruang bakar. Akan tetapi, hasil uji modifikasi menunjukkan penurunan daya keluaran pada mesin genset berbahan bakar biogas karena perbedaan nilai kalor kedua bahan bakar (Rosli 2002; Stefan 2004). Ehsan dan Naznin (2005) menyimpulkan perlunya penurunan laju alir udara sebanding dengan proporsi penurunan kandungan metan pada biogas. Mesin genset beroperasi pada pembebanan dan putaran relatif konstan membutuhkan laju alir udara maksimum yang terbatas. Volume jenis biogas lebih besar dibandingkan dengan bahan bakar cair menyebabkan penurunan laju alir udara sehingga biogas dengan kandungan $60 \%$ metan mengalami penurunan daya keluaran genset sebesar $0.8 \mathrm{~kW}$. Namun penelitian tersebut menyimpulkan mesinbiogas menghasilkan emisi $\mathrm{CO}, \mathrm{CO}_{2}$ dan $\mathrm{HC}$ yang rendah (Joshi et al. 2015).

Karena itu biogas dapat digunakan sebagai bahan bakar untuk memenuhi tujuan penggunaan biogas produk digester dengan bahan baku berasal dari lingkup pertanian di perdesaan. Penelitian ini bertujuan untuk merancang bangun dan menguji secara eksperiment alat pencampur udara-biogas yang berfungsi seperti karburator tanpa merubah mesin uji.

\section{Bahan dan Metode}

Perancangan dilakukan melalui analisis termodinamika siklus Otto (Cengel dan Boles 2002; Moran dan Saphiro 2006), sistim aliran pada pencampuran udara-bahan bakar dihitung sesuai kebutuhan pembakaran maksimum pada motor Otto. Pembakaran tergantung pada nilai kalor terendah (lower heating value/LHV) dari gas metana pada biogas. Perancangan berdasarkan persyaratan yang baku dengan pertimbangan mesin dapat beroperasi, beberapa dimensi komponen merujuk pada mesin yang tersedia, variasi beban listrik mengikuti mekanisme throttle dan governor mesin, tahan terhadap kondisi operasi mesin, mudah dilepas dan dipasang kembali saat perawatan dan pemeliharaan termasuk saat dikembalikan pada pengoperasian aslinya. Adapun tahapan perancangan dan pabrikasi prototipe alat pencampur udara-biogas berdasarkan pada kriteria baku meliputi identifikasi masalah, perumusan pemecahan masalah, rancangan fungsional, rancangan struktural, gambar teknik, dan fabrikasi. Sedangkan rancangan struktural alat pencampur memenuhi kriteria berdasarkan analisis teknik pemilihan bahan, kekuatan dan penentuan parameter desain.

Dimensi distributor biogas dan penghalang heliks dirancang berdasarkan analisis termodinamika siklus Otto dan kebutuhan udara untuk pembakaran sempurna. Penghalang heliks berada didalam suatu selongsong silinder yang ditempatkan sebelum intake manifold. Melalui analisis termodinamika siklus Otto aliran pada pencampuran udara-bahan bakar dihitung berdasarkan pada kebutuhan pembakaran dengan nilai kalor terendah sesuai kandungan metan pada biogas. Pengujian kandungan gas metan pada biogas dilakukan dengan sensor metan dan data yang diperoleh menunjukkan presentase konsentrasi gas $\mathrm{CH}_{4}$ pada biogas. Dari hasil pengukuran diperoleh konsentrasi rata-rata metan pada biogas sebesar $57.5 \%$. Perhitungan terkait kebutuhan pembakaran motor Otto menggunakan persamaan 1 hingga 6.

1. Massa bahan bakar dan laju aliran massa terisap kedalam ruang bakar (intake volumetric) masing-masing:

$M=\frac{P_{1} V_{1}}{\left(\frac{\dot{R}}{M}\right) T_{1}} ; \dot{m}=\frac{(A . V) P}{v \cdot T_{1}}=\frac{(\text { A.V } P}{\left(\frac{\dot{R}}{M}\right) \cdot T_{1}}$

2. Massa bahan bakar per-siklus,

$$
M_{f}=\frac{m}{(A F R+1)}
$$

3. Kerja siklus,

$$
W_{\text {cycle }}=m\left[\left(u_{3}-u_{4}\right)-\left(u_{2}-u_{1}\right)\right]
$$


4. Tekanan efektif rata-rata,

$$
\text { mep }=\frac{W_{\text {cycle }}}{V_{1}-V_{2}}=\frac{W_{\text {cycle }}}{V_{1}\left(1-\frac{V_{2}}{V_{1}}\right)}
$$

5. Efisiensi termis,

$$
\eta_{t h}=1-\frac{u_{4}-u_{1}}{u_{3}-u_{2}}
$$

6. Daya indikatif,

$$
P_{i}=\dot{m} . L H V
$$

Keterangan: $\mathrm{m}$ adalah massa fluida yang terisap ke dalam silinder, $\mathrm{kg} ; \dot{m}=$ laju alir biogas, $\mathrm{kg} / \mathrm{s} ; \eta_{\text {th }}$ : volume fluida yang terisap ke dalam silinder dengan volume langkah piston; $\mathrm{P} 1=1.01325$, bar; $V_{\text {sil }}=V_{1}$ $=222, \mathrm{~cm}^{3} ; \dot{R}_{\text {gas }}=8.314, \mathrm{~kJ} / \mathrm{kg} . \mathrm{K} ; M=28.97, \mathrm{~kg} . \mathrm{K}$; $T=298.15, \mathrm{~K} ; u=$ energy dalam, $\mathrm{kJ} / \mathrm{kg} ; \rho=$ rapat masa, $\mathrm{kg} / \mathrm{m}^{3} ; P_{i}=$ daya indikatif, $\mathrm{kJ}$.

Nilai kalor terendah (lower heating value/LHV) gas metana diperoleh dari hubungan kandungan metan, densitas dan nilai kalor normalnya seperti pada persamaan 7 , sedangkan rasio udara terhadap bahan bakar biogas dihitung berdasarkan persamaan 8 dan 9 .

$$
\begin{aligned}
& L H V_{\text {biogas }}=\% \mathrm{CH}_{4} * \mathrm{LHV}_{\mathrm{CH}_{4}} \\
& \mathrm{LHV}_{\mathrm{CH}_{4}}=\rho_{\text {biogas }} * L H V_{\text {normal }} \\
& =\frac{V_{C_{4}}}{V_{\text {total }}} * \rho_{\mathrm{CH}_{4}} * L H V_{\text {normal }} \\
& \left(a \mathrm{CH}_{4}+b \mathrm{CO}_{2}\right)+c\left(\mathrm{O}_{2}+3.76 \mathrm{~N}_{2}\right) \rightarrow \\
& d \mathrm{H}_{2} \mathrm{O}+e \mathrm{CO} 2+f \mathrm{~N}_{2}+\text { Energi } \\
& A F R_{\text {s-biogas }}=\frac{c\left(\mathrm{O}_{2}+3.76 \mathrm{~N}_{2}\right)}{a \mathrm{CH}_{4}+\mathrm{bCO}_{2}}
\end{aligned}
$$

Perhitungan dimensi penghalang heliks merupakan fungsi dari laju aliran, bilangan Reynold, head losses (saluran utama, sepanjang penghalang heliks dan elbow) serta penurunan tekanan (pressure drop). Kecepatan aliran tergantung pada sudut heliks, tekanan dan bentuk geometri kinematic secara fluida dinamik. Hubungan antara komponen gaya dan kecepatan aliran tergantung pada sudut heliks, tekanan sistem dan bentuk geometri alat penghalang heliks. Persamaanpersamaan berikut digunakan untuk perhitungan gaya-gaya pada penghalang heliks. Dengan prinsip konservasi massa di sepanjang penghalang heliks, laju aliran massa campuran masuk tetap $\left(m_{1}=m_{2}\right)$ untuk keadaan tanpa penghalang heliks (1) dan yang menggunakan penghalang heliks (2), berlaku hubungan:

$\rho_{1} v_{1} A_{1}=\rho_{2} v_{2} A_{2}$

Untuk aliran dalam penampang yang sama $A_{1}=A_{2}$, dan hubungan antara tekanan $\mathrm{P}$ dan kerapatan $\rho$ untuk gas ideal berlaku:
$P=\rho R T$

Suhu campuran kedua keadaan tersebut diasumsikan sama hingga masuk ruang bakar, sehingga :

$\frac{P_{1}}{\rho_{1}}=\frac{P_{2}}{\rho_{2}}$

Faktor gesekan (friction loosses) disepanjang penghalang heliks menyebabkan penurunan tekanan; sehingga tekanan campuran keluar penghalang heliks lebih rendah dibandingkan dengan tanpa menggunakan penghalang heliks; akibatnya kerapatan pada keadaan (2) akan lebih rendah dibandingkan dengan keadaan (1). Maka dari persamaan (3.26) berlaku $\rho_{1}>\rho_{2}$ dan kecepatan aliran melalui penghalang heliks lebih besar dibandingkan dengan kecepatan aliran melalui tanpa penghalang heliks yang masuk kedalam ruang bakar $v_{2}>v_{1}$

Dari persamaan trigonometri, kecepatan alir arah tangensial yang membentuk sudut heliks $(\psi)$ lebih besar dibandingkan dengan kecepatan arah aksial yang besarnya dihitung berdasarkan:

$v_{t}=\frac{v_{a}}{\cos \psi}$

Debit aliran arah tangensial lebih besar dari arah aksial, diperoleh dengan persamaan dan batasan sudut heliks:

$Q_{t}=v_{t} A$ dan $Q_{a}=v_{a} A$

$\operatorname{Cos} \psi<1$ dan $0^{\circ}<\psi<45^{\circ}$, maka $v_{t}>v_{a}$ dan panjang lintasan penghalang heliks dihitung dengan

$L=\pi d \tan (90-\psi) l$

Keterangan: $v_{t}$ : kecepatan tangensial $(\mathrm{m} / \mathrm{s}) ; A$ : area penampang $\mathrm{p} / \mathrm{h}\left(\mathrm{mm}^{2}\right) ; \psi$ : sudut penghalang heliks terhadap sumbu aksial $\left(^{\circ}\right)$; $Q$ : laju alir keluar penghalang heliks $(\mathrm{g} / \mathrm{s}) ; L$ : panjang lintasan penghalang heliks $(\mathrm{mm}) ; \mathrm{I}$ : panjang selongsong penghalang heliks; $d$ : diameter penghalang heliks $(\mathrm{mm}) ; v_{t}, v_{a}$ : kecepatan aliran arah tangensial dan aksial $(\mathrm{m} / \mathrm{s})$.

Laju aliran masa melalui nosel dan diameter lubang keluar dapat menurunkan tekanan sistim dan kecepatan tangensial (Taiwo et al. 2008). Perhitungan menggunakan persamaan 16 dan 17.

1. Laju aliran massa,।

$$
\dot{m}=A_{2} \sqrt{\frac{2\left(p_{1}-p_{2}\right)}{\rho\left[1-\left({ }^{A_{2}} / A_{1}\right)^{2}\right]}}
$$




\section{Pressure drop pada intake manifold,}

$$
\Delta p=\gamma\left(h_{l}+h_{e l}\right)
$$

Keterangan: $p=$ tekanan sistim, $\mathrm{kPa} ; \Delta p=$ Pressure drop, $\mathrm{kPa} ; \gamma=$ massa jenis, $\mathrm{kg} / \mathrm{m}^{3} ; \rho=$ rapat masa, $\mathrm{kg} / \mathrm{m}^{3} ; \dot{m}=$ laju aliran massa, $\mathrm{kg} / \mathrm{s} ; A=$ penampang saluran, $\mathrm{m}^{2} ; h_{l}=$ head losses linear pada saluran, $\mathrm{m} ; h_{e l}=$ head losses pada elbow, $\mathrm{m}$.

Untuk pemenuhan kebutuhan bahan bakarsesuai kapasitas motor Otto yang dirujuk melalui simulasi desain secara termodinamika meliputi aliran massa dan laju aliran bahan bakar yang masuk kedalam ruang bakar (intake volumetric). Pertama, simulasi untuk berbagai rasio kompresi yaitu 7.0 hingga 12.5, dan hasil simulasi perhitungan dari berbagai parameter pembakaran ditampilkan seperti pada Tabel. 2. Kedua, simulasi perancangan alat pencampur terhadap debit campuran. Kemudian, dari debit alir menghasilkan energy pembakaran dan parameter pembakaran seperti ditampilkan pada Gambar 3. Parameter pembakaran pada rasio kompresi 8.5 masing-masing diperoleh debit campuran $0.135 \mathrm{~g} / \mathrm{s}$, massa campuran $0.233 \mathrm{~g}$, kerja $W$-cyc $0.13 \mathrm{~kJ}$, efisiensi termis 0.51 , efisiensi volumetrik 0.74 dan tekanan efektif rata-rata 5.476 bar ditampilkan pada Tabel 2.

Uji secara eksperimen dilakukan pada motor Otto 4-langkah silinder tunggal penggerak genset (Tabel 1) dan pengambilan data uji melalui berbagai alat ukur ditampilkan pada konfigurasi Gambar

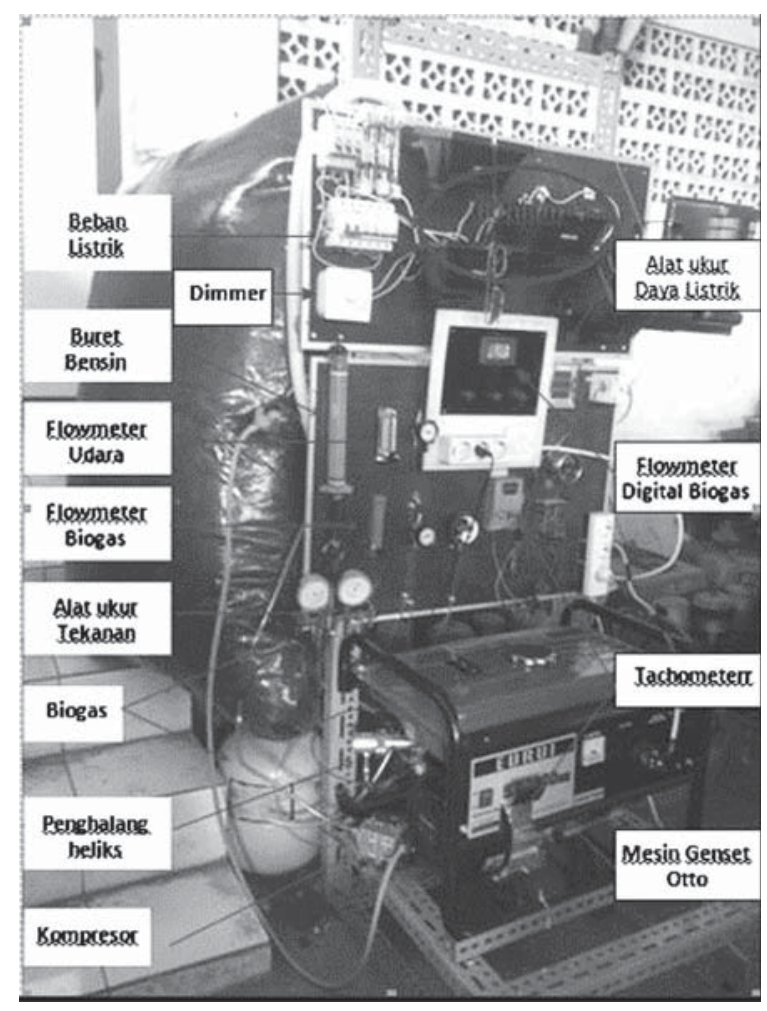

Gambar 1. Konfigurasi mesin uji dilengkapi berbagai alat ukur.
Tabel 1. Spesifikasi teknik motor Otto 4-langkah silinder tunggal penggerak genset.

\begin{tabular}{lcc}
\hline Parameter Desain & Spesifikasi & Satuan \\
\hline Merek/tipe & Eurui & - \\
& 1-silinder & - \\
& 4 -langkah & - \\
Daya & 2.0 & $\mathrm{~kW}$ \\
Diameter silinder & 68 & $\mathrm{~mm}$ \\
Langkah & 54 & $\mathrm{~mm}$ \\
Rasio kompresi & 8.5 & - \\
Volume silinder & 222 & $\mathrm{cc}$ \\
Bahan bakar & bensin & - \\
\hline
\end{tabular}

2. Bahan bakar biogas yang digunakan memiliki kandungan metana rata-rata $57.5 \%$ dan bahan bakar bensin berkadar oktana 90 (pertalite).

Pembebanan motor menggunakan lampu pijar dengan tahapan penyalaan lampu pijar secara berurutan (1, 2, 3 dst) dengan daya masing-masing $0.3 \mathrm{~kW}$ pada penggunaan masing-masing kedua jenis bahan bakar. Berbagai peralatan ukur yang digunakan dalam pengambilan data eksperimen yaitu: flowmeter, anemometer, tachometer, voltampher meter, alat uji emisi. Untuk mengukur debit udara yang dibutuhkan motor Otto dengan menggunakan anemometer yang dipasang melalui saluran utama udara sebelum intake manifold. Sebagi pembanding pengukuran debit udara juga menggunakan flowmeter yang dipasang pada saluran utama udara. Demikian juga untuk mengukur debit biogas menggunakan flowmeter yang dipasang melalui saluran utama udara sebelum intake manifold. Untuk mengukur debit bahan bakar bensin yang terpakai dalam satu satuan waktu tertentu digunakan gelas ukur. Pencatatan data pada sisi luaran generator listrik meliputi voltase, ampere dan frekuensi dengan menggunakan volt-ampher meter. Untuk pencatatan daya listrik keluaran maksimum yang dihasilkan generator, pencatatan pada pembebanan akhir melalui dimmer. Untuk mengukur emisi gas buang meliputi $\mathrm{CO}, \mathrm{CO}_{2}$ dan $\mathrm{HC}$ melalui saluran gas buang (exhaust manifold) dengan menggunakan alat uji emisi Sukyong SYGA 401. Untuk mendapatkan data yang akurat maka mekanisme pengambilan data selama pengujian berlangsung dengan melakukan beberapa kali pengulangan pengukuran. Adapun perhitungan kinerja listrik luaran generator menggunakan persamaan 18 hingga 20 berikut:

1. Daya genset:

$$
P_{g}=V \cdot A
$$

2. SFC (specific fuel consumption):

$$
S F C=\eta_{e l} \cdot \frac{\dot{m}}{P_{i}}
$$


Tabel 2. Kinerja secara termodinamika dari mesin ber bahan bakar bensin dan biogas.

\begin{tabular}{lcccccccccccccc}
\hline \multicolumn{1}{c}{} & \multicolumn{1}{c}{ Bensin } & \multicolumn{11}{c}{ Biogas } \\
\hline Rasio komp. & & 8.5 & 7.0 & 8.0 & 8.5 & 8.8 & 9.1 & 9.7 & 10.1 & 10.5 & 10.9 & 11.4 & 11.9 & 12.5 \\
W(cycle) & $\mathrm{kJ}$ & 0.155 & 0.138 & 0.135 & 0.138 & 0.141 & 0.144 & 0.139 & 0.146 & 0.142 & 0.138 & 0.149 & 0.140 & 0.147 \\
mep & $\mathrm{bar}$ & 6.162 & 4.643 & 4.741 & 4.929 & 5.090 & 5.248 & 5.148 & 5.436 & 5.336 & 5.218 & 5.675 & 5.404 & 5.721 \\
Ef. Termis & $\%$ & 51.19 & 49.64 & 49.65 & 51.19 & 52.65 & 54.06 & 52.59 & 53.84 & 54.06 & 52.65 & 57.01 & 54.06 & 56.98 \\
Debit bb & $\mathrm{g} / \mathrm{s}$ & 0.250 & 0.139 & 0.136 & 0.135 & 0.134 & 0.134 & 0.133 & 0.132 & 0.132 & 0.131 & 0.131 & 0.130 & 0.129 \\
\hline
\end{tabular}

3. Efisiensi termis:

$\eta_{t}=\frac{P_{g}}{\dot{m} \cdot L H V}$

Keterangan: $P_{g}=$ daya listrik genset, $\mathrm{kW} ; \eta_{\mathrm{el}}=$ efisiensi elektrikal; $V_{c y l}=$ volume ruang bakar, $\mathrm{cm}^{3}$; $\dot{m}=$ laju alir biogas, $\mathrm{kg} / \mathrm{s} ; V=$ voltase terukur, volt; $A$ $=$ arus terukur, amp; SFC = konsumsi bahan bakar spesifik, kg/kW-h.

\section{Hasil dan Pembahasan}

\section{Rancang-bangun Sistem Pencampur Udara- Biogas}

Perencanaan simulasi desain secara termodinamika dilakukan sesuai spesifikasi teknis mesin uji, dengan kriteria kinerja seperti ditampilkan dalam Tabel 2 dengan hasil simulasi rancangan untuk rasio kompresi 7.0 hingga 12.5 , ditampilkan pada Tabel 2. Kemudian perhitungan selanjutnya menggunakan rasio kompresi $(r c=8.5)$ sesuai mesin uji. Dengan penyesuaian dimensi karburator mesin yang dirujuk, diperoleh dimensi rinci hasil rancangan. Diameter dan panjang distributor biogas masing-masing $18 \mathrm{~mm}$ dan $50 \mathrm{~mm}$, diameter lubang nosel $2 \mathrm{~mm}$ dan ber jumlah 8 . Dan hasil simulasi diperoleh panjang penghalang heliks yaitu $39 \mathrm{~mm}$, membentuk sudut heliks $30^{\circ}$ dan diameter poros $2 \mathrm{~mm}$, sebagai dimensi yang paling sesuai untuk mesin uji. Gambar rinci alat pencampur udarabiogas ditampilkan pada Gambar 2.

Hasil perhitungan desain kinerja mesin secara numerik dalam kajian analisis termodinamika pada siklus standar udara motor Otto dan kajian dinamika fluida menggunakan prinsip konservasi massa pada aliran campuran udara-biogas melalui alat pencampur ditampilkan pada Gambar 3.

Hasil simulasi menunjukkan kinerja mesin mengalami kenaikan secara bertahap ketika
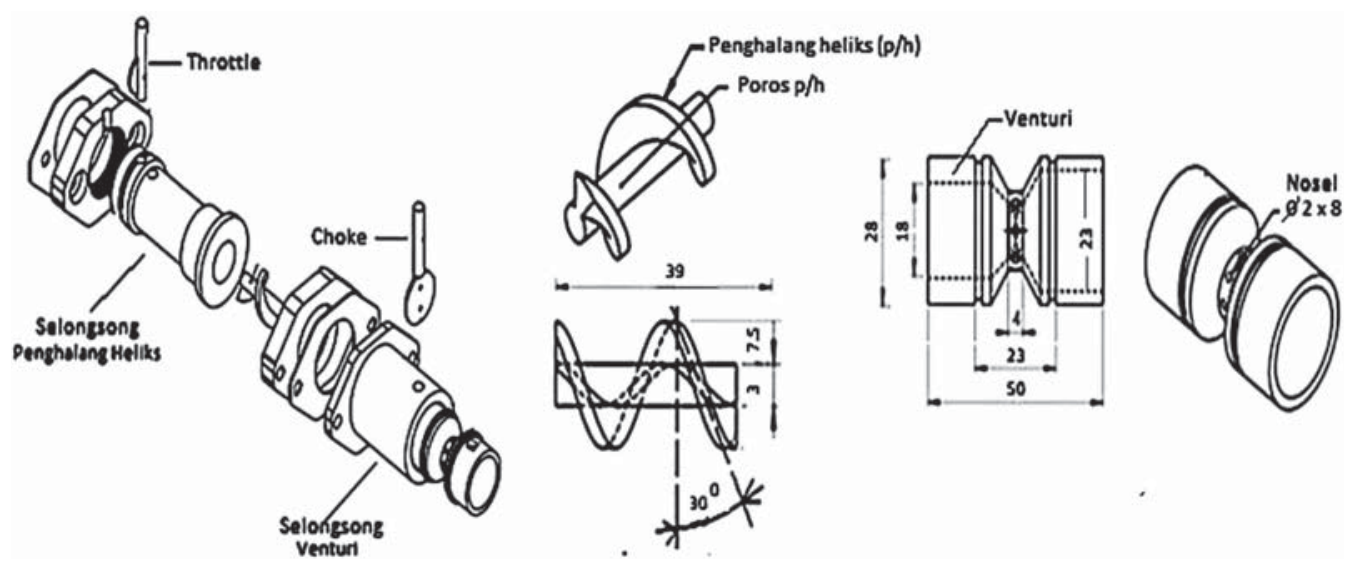

Gambar 2. Detail distributor dan penghalang heliks pencampur udara-biogas.

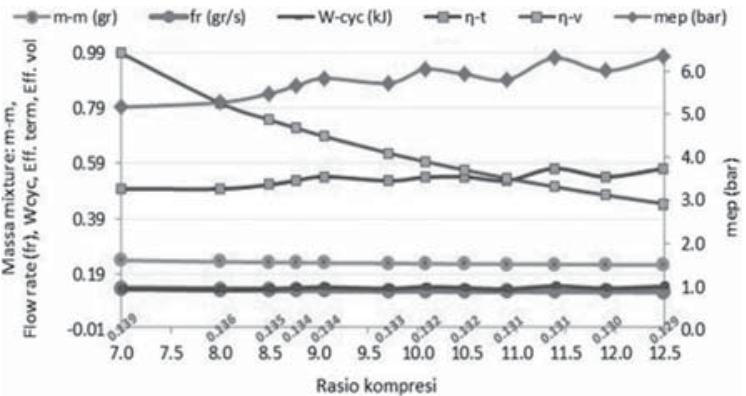

Gambar 3. Performa secara termodinamika bahan bakar biogas untuk berbagai variasi rasio kompresi.

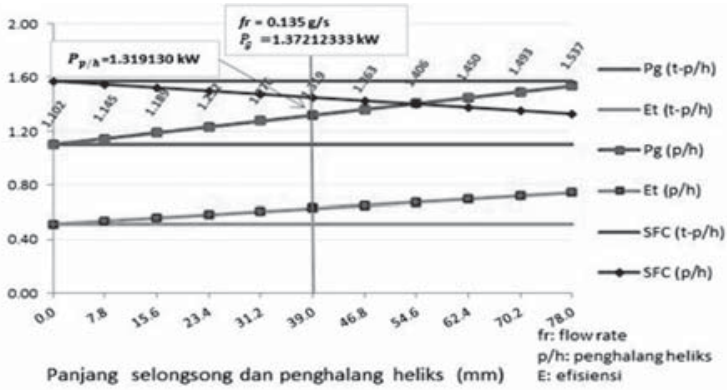

Gambar 4. Kinerja mesin dengan menggunakan penghalang heliks dan tanpa penghalang heliks. 
Tabel 3. Dimensi penghalang heliks sebagai alat pencampur udara-biogas hasil rancangan.

\begin{tabular}{lcc}
\hline Parameter & Ukuran & Satuan \\
\hline Diameter dan Jumlah nosel & $2 / 8$ & $\mathrm{~mm}$ \\
Diameter saluran & 18 & $\mathrm{~mm}$ \\
Diameter poros penghalang heliks & 2 & $\mathrm{~mm}$ \\
Panjang distributor biogas & 50 & $\mathrm{~mm}$ \\
Panjang selongsong penghalang heliks & 78 & $\mathrm{~mm}$ \\
Panjang penghalang heliks & 39 & $\mathrm{~mm}$ \\
Sudut penghalang heliks & 30 & ${ }^{\circ}$ \\
\hline
\end{tabular}

udara-biogas melewati penghalang heliks. Kinerja pembakaran untuk mototr Otto yang dirujuk menunjukkan bahwa panjang penghalang heliks yang dapat digunakan adalah $39 \mathrm{~mm}$. Hasil simulasi jika menggunakan penghalang heliks pada jarak tersebut menghasilkan daya listrik sebesar $1.319 \mathrm{~kW}$ dan jika tanpa penghalang heliks lebih rendah yaitu sebesar $1.258 \mathrm{~kW}$. Dengan demikian, penghalang heliks dapat memberi pengaruh yang baik terhadap efektivitas dan efisiensi pembakaran sehingga menghasilkan daya yang lebih besar.

Untuk mengetahui performansi motor Otto berbahan bakar biogas melalui pengujian terhadap hasil simulasi tersebut, maka dilakukan pabrikasi alat penghalang heliks dengan panjang $39 \mathrm{~mm}$ diameter penghalang $2 \mathrm{~mm}$ dan sudut heliks adalah 30 derajat. Data rinci alat pencampur sebagaimana ditampilkan pada Gambar 2 dan dioperasikan sebagai pencampur udara-biogas menggunakan motor Otto sesuai dengan spesifikasi yang dirujuk ditunjukkan pada Tabel 1.

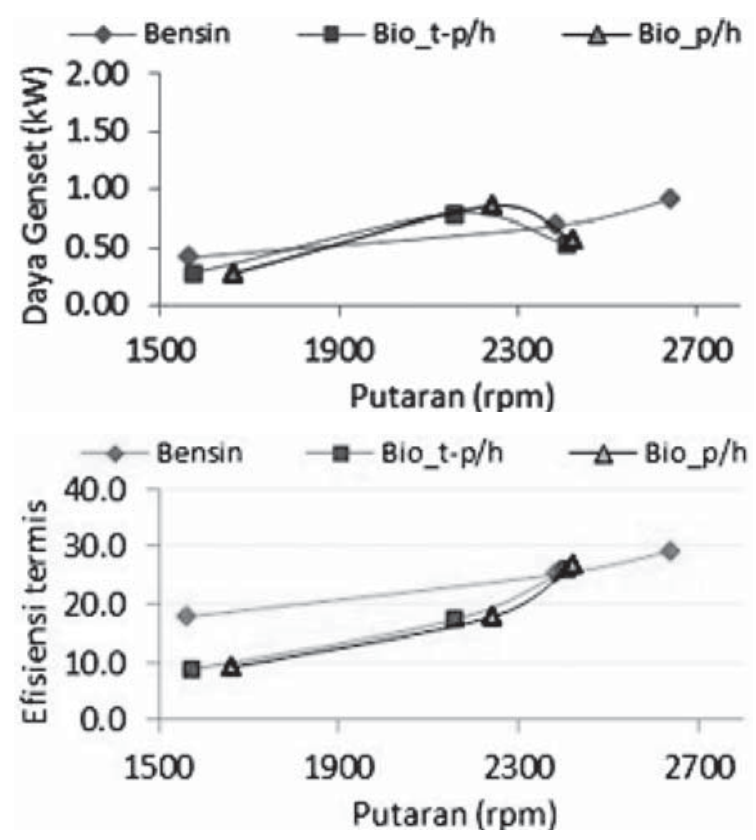

Gambar 5. Perbandingan daya mesin dan efisiensi termis mesin ber bahan bakar bensin dan biogas.

\section{Pengujian Alat Pencampur Udara-Biogas}

Gambar 5 menunjukkan daya dan efisiensi termis hasil pengukuran dari uji eksperimental alat pencampur udara-biogas dengan dan tanpa penghalang heliks. Perbedaan jumlah lampu pijar digunakan untuk variasi beban pada genset.

Gambar 5 menunjukkan pengujian dengan menggunakan bahan bakar biogas daya listrik yang dihasilkan lebih rendah $17 \%$ dibandingkan dengan daya mesin berbahan bakar bensin (pertalite). Selanjutnya, Gambar 5 juga menunjukkan efisiensi termis mesin berbahan bakar biogas lebih rendah dibandingkan dengan mesin orisilnya. Sementara itu, penggunaan penghalang heliks untuk pencampuran udara-biogas tidak menunjukkan perbedaan efisiensi termis. Hal ini diduga sebagai akibat dari nilai kalor biogas yang lebih rendah sebagaimana hal yang sama diperoleh dari beberapa hasil penelitian sebelumnya (Roger 1985; Rakesh dan Patel 2015; Heywood 1988, Rosli 2002; Ehsan dan Naznin 2005).

Pada pembebanan 3 lampu pijar, daya yang diperoleh tanpa penghalang heliks adalah 0.79 $\mathrm{kW}$ sementara dengan penghalang heliks adalah $0.85 \mathrm{~kW}$. Hasil pengukuran ini lebih rendah dari hasil simulasi, yaitu $1.319 \mathrm{~kW}$ dan $1.258 \mathrm{~kW}$, masing-masing untuk pencampuran dengan dan tanpa penghalang heliks. Akan tetapi, peningkatan daya yang dihasilkan sebagai akibat penggunaan penghalang heliks pada pencampur udara-biogas dapat dibuktikan. Peningkatan daya tersebut menunjukkan mutu campuran udara-biogas lebih homogen sehingga menghasilkan pembakaran yang lebih baik.

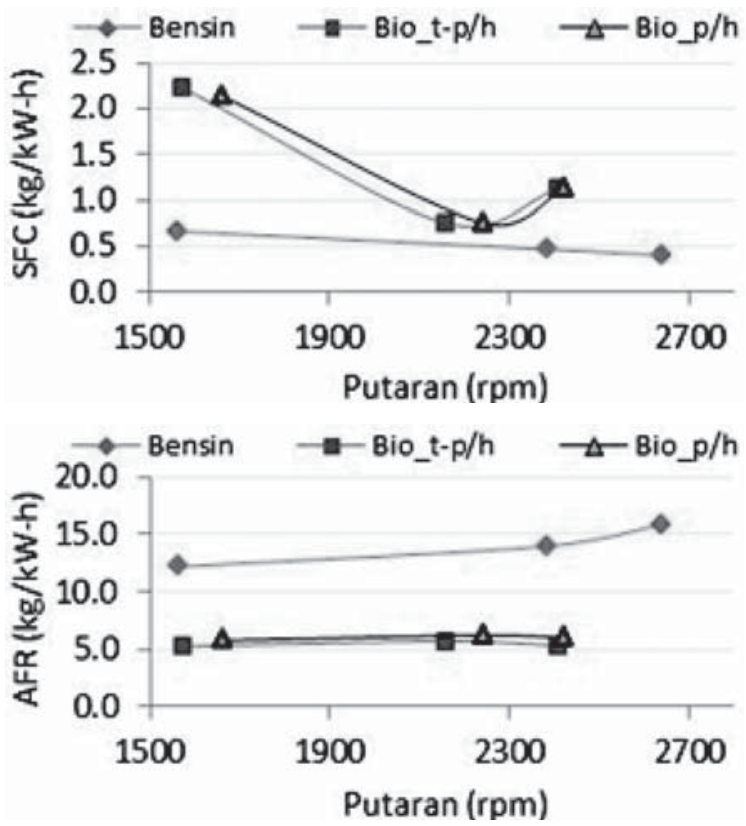

Gambar 6. Perbandingan SFC dan AFR dari mesin berbahan bakar biogas dan bensin. 
Gambar 6. menunjukkan hasil pengolahan data pengukuran meliputi: konsumsi bahan bakar spesifik (specific fuel consumption/SFC) dan rasio udara terhadap bahan bakar (air to fuel ratio/AFR), pada 3 tingkat pembebanan. SFC mesin dengan bahan bakar biogas pada beban menengah menggunakan penghalang heliks dan tanpa penghalang heliks relatif sama, yaitu berkisar $0.79 \mathrm{~kg} / \mathrm{kW}$-h, sedangkan SFC mesin yang menggunakan bahan bakar bensin adalah $0.41 \mathrm{~kg} / \mathrm{kW}$-h.

Sesuai dengan argument sebelumnya, perbedaan tersebut disebabkan rendahnya nilai kalor biogas. Selanjutnya, rasio udara-biogas (AFR) untuk penggunaan biogas relatif tetap dan berkisar pada nilai stoikiometrik yaitu 5.5 hingga 5.8 ). AFR untuk penggunaan bahan bakar bensin yang terukur sebesar 12.2 lebih rendah dari nilai stoikiometrik. Hal ini menunjukkan pembakaran berlangsung dengan kekurangan udara (pembakaran tidak sempurna) dapat menghasilkan emisi gas buang (Heywood 1988; Ganesan 1987; Roger 1985).

Gambar 7 menampilkan hasil pengukuran emisi gas buang dengan emisi $\mathrm{CO}$ dan $\mathrm{HC}$ dari mesin bensin lebih tinggi masing-masing 10\% dan sebesar 1.5 kali lebih tinggi dibandingkan dengan emisi mesin berbahan bakar biogas. Pembentukan $\mathrm{CO}$ terjadi akibat pembakaran yang tidak sempurna disebabkan kekurangan oksigen, disamping gagalnya pembentukan $\mathrm{CO}_{2}$ (dissosiasi) pada daerah bersuhu tinggi (Heywood 1988; Roger 1985). Disamping itu, sebagian campuran udarabahan bakar bensin masuk dan terjebak di celahcelah antara piston, piston ring dan silinder (crevice volume) dimana sebagian menempel dan tidak ikut terbakar. Sehingga penggantian karburator dengan sistem pencampur udara-biogas yang

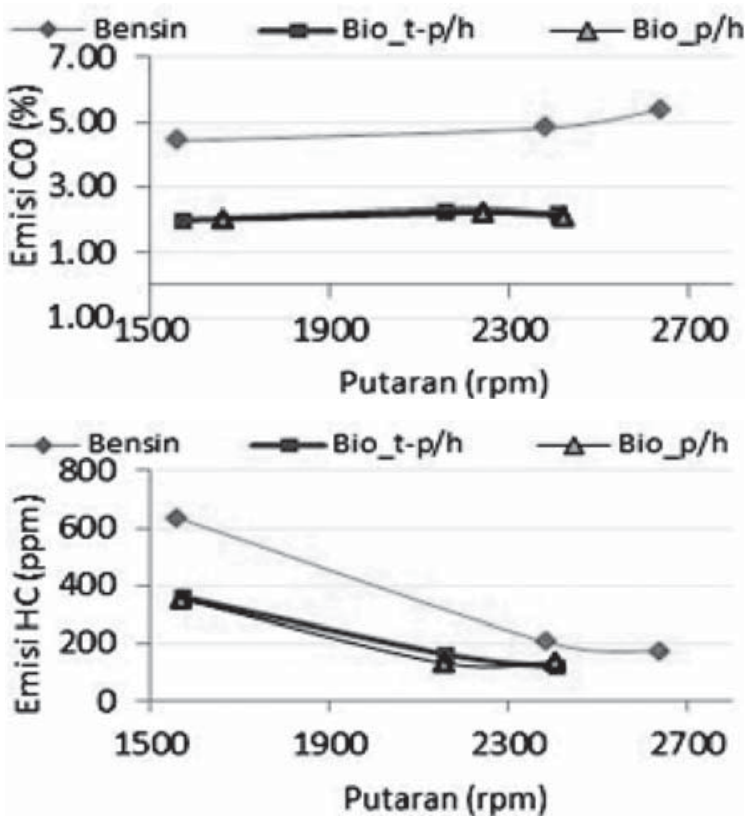

Gambar 7. Perbandingan emisi gas buang mesin ber bahan bakar bensin dan biogas. menggunakan penghalang heliks menghasilkan pembakaran yang lebih sempurna sehingga mengurangi terbentuknya emisi polusi di dalam gas buang.

\section{Simpulan}

Hasil simulasi terhadap rancang bangun pada penghalang heliks, dengan panjang 39 $\mathrm{mm}$ dan sudut heliks 30 derajat sebagai sistem pencampur udara-biogas merupakan dimensi yang paling sesuai untuk digunakan pada motor Otto penggerak generator listrik yang dirujuk. Hasil simulasi menunjukkan penggunaan penghalang heliks sebagai sistem pencampur udara-biogas dapat meningkatkan daya luaran sebesar $5 \%$ dan menurunkan konsumsi bahan bakar spesifik sebesar $8 \%$. Dari hasil uji eksperiment terhadap performansi penghalang heliks yang didasarkan pada simulasi tersebut juga menunjukkan hal yang sesuai, yaitu peningkatan $5 \%$ daya dan penurunan $4.5 \%$ konsumsi bahan bakar spesifik. Disamping itu, penggantian karburator dengan sistem pencampur hasil rancangan juga berdampak pada pengurangan emisi $\mathrm{CO} 10 \%$ dan $\mathrm{HC}$ sebesar 1.5 kali sebagai akibat rasio udara-biogas (AFR) relatif tetap berkisar stoikiometrik sehingga menghasilkan pembakaran relatif lebih sempurna.

\section{Daftar Pustaka}

Awogbemi, Omojola, Adeyemo and S. Babatunde. 2015. Development And Testing Of BiogasPetrol Blend as an Alternative Fuel For Spark Ignition Engine. International Journal of Scientific \& Technology Research. 4 (9) pp.179-185.

Cengel.Y.A. dan M.A. Boles.2002. Thermodynamics, An Engineering Approach. The Mc Graw-Hill Company.

Deublein, D. and A. Steinhauser. 2008. Biogas from Waste and Renewable Resources. An Introduction. Wiley-Vch Verlag $\mathrm{GmbH}$ \& Co. KGaA. Weinheim. Heidelberg ISBN: 978-3-52731841-4

Ehsan, M.D. and N. Naznin. 2005. Performance of a Biogas Run Petrol Engine for Small Scale Power Generation. Journal of Energi \& Environment, pp.1-9.

Ganesan, V. 1987. Internal Combustion Engines. Third Edition. Education Private. Tata McGrawHill Publishing Co. Limited. New Delhi.

Heywood, J.B. 1988. Internal Combustion Engine Fundamental. Mc Graw Hill. Singapore.

Joshi, A.B., P.B. Umrigar, A.B. Patel dan K.A. Patel. 2015. Using Biogas in SI Engine by Changing Ignition Parameter and Compression Ratio. International Jurnal for Scientific Research \& Development. 3 (2). 
Mohan, K. dan Azad. 2014. An Experimental Investig Eschbornation of Performance and Emissions of LPG as Dual Fuel in Diesel Engine Generator. Int. Journal of Engineering Research and Applications. 4 ( 11): 41-53.

Mitzlaff, K.V. 1988. Engines for biogas, Theory, Modification, Economic Operation. A publ. of Dt. Zentrum für Entwicklungstechnologien-Gate in: Dt.Ges. fur Techn. Zusammenarbeit (Gtz) $\mathrm{GmbH}$. Africa

Moran, M.J. dan H.N. Saphiro. 2006. Fundamentals Engineering Thermodynamics. 5th editions. John Willey and Sons, Inc. England UK.

Rakesh, C.K. dan K.L. Patel. 2015. To Evaluate The Performance And Measurement Of Polution In IC Engine Using Biogas. International Journal of Advance Research in Engineering, Science \& Technology. 2 (5): 1-4.
Roger, A.S. 1985. Combustion Fundamentals. International Student Edition. Mc Graw Hill-Book Co. Singapore.

Rosli, A. 2002. Design and Development of a New CNG (Compressed Natural Gas) Engine. Pusat Pengurusan Penyelidikan Universiti Teknologi. Malaysia.

Mihić, S. 2004. Biogas Fuel For Internal Combustion Engine. Annuals of The Faculty of Engineering Hunedoara. 2(3); pp. 179-190.

Taiwo, A. dan K. Oje. 2008. Development and Testing of a Swirl Chamber Nozzle. Journal of Agricultural Engineering and Technology, 16 (1) pp. 12-24.

Theodorita, A.S., R. Dominik, P. Heinz, F. Tobias, V. Silke dan J, Rainer. 2008. Biogas Handbook, University of Southern Denmark, BiG East Project, Esbjerg, Denmark. 


\section{Indeks Penulis}

Jurnal Keteknikan Pertanian Volume 8 Tahun 2020

Abdullah bin Arif, 29

Ahmuhardi Abdul Azis, 45

Andi Ani Kuswati, 15

Ari Hayati, 81

Armansyah Halomoan Tambunan, 39, 53, 89

Bambang Pramudya, 63

Budi Santoso, 113

Dadan Kusdiana, 39

Darma, 113

Desrial, 89

Dwi Zuwarman, 1

Edy Hartulistiyoso, 39, 53

Emmy Darmawati, 15, 63, 97, 105

Evi Savitri Iriani, 71

Fajar Kurniawan, 71

Hasbi, 81

Hendri Syah, 53

Herbert Hasudungan Siahaan, 89

I Dewa Made Subrata, 9

I Wayan Budiastra, 45

Inge Scorpi Tulliza, 39
Lamhot Parulian Manalu, 53

Marisa Tri Amanah, 81

Nafilawati Wa Ode, 97

Nurul Khumaida, 97

Reniana, 113

Riska Juliana, 23

Rismen Sinambela, 9

Rokhani Hasbullah, 1, 23

Sandro Pangidoan Siahaan, 29

Sari Intan Kailaku, 29

Soni Solistia Wirawan, 89

Siti Mariana Widayanti, 15

Sri Lestari, 71

Sutrisno Suro Mardjan, 1, 23, 45, 63, 97, 105

Syamsul Bahri, 63

Tatang Hidayat, 29

Tineke Mandang, 9

Usman Ahmad, 71

Wawan Hermawan, 9

Yandri Iskandar Pah, 105 


\section{Indeks Subjek}

Jurnal Keteknikan Pertanian Volume 8 Tahun 2020

ASLT Method, 23

Biodiesel, 39

Biogas, 89

Catalyst, 39

Curing, 29

Cylinder type, 113

Distribution centers, 63

Dormancy, 29

Drying model, 53

Drying rate, 53

Edible coating, 105

Energy ratio, 39

Engine performance, 89

Expiration date, 23

Exposure duration, 15

Extraction, 45

Fresh Fruit Bunch, 9

Genotipe, 97

Good Handling Practices, 1

Good Manufacturing Practices, 1

Growth power, 29

Hellical barrier, 89
Immersion temperature, 81

Irradiation, 71

Moisture sorption isotherm, 23

Oil palm, 9

Oleoresin, 45

Optimum Ripeness Position, 9

Ozon, 15

Peleg model, 81

Physicoshemical, 97

Rasping performance, 113

Rehydration, 81

Rice Milling Unit, 1

Rotation speed, 113

Static mixer reactor, 39

Storage, 29, 71

Teeth diameter, 113

Temperature, 29

Thin layer drying, 53

Total Plate Count, 15

Ultrasound, 45

Yield, 45 